\title{
PERBANDINGAN MUTU BERDASARKAN PROFIL DISOLUSI TABLET GLIBENKLAMID PATEN DAN GENERIK YANG BEREDAR DI MAKASSAR
}

\section{A. Mumtihanah Mursyid, Nursiah Hasyim, Evy Fajrianti Jauhari}

\author{
Fakultas Farmasi Universitas Muslim Indonesia, Makassar \\ Email : mumtihanah.mursyid@umi.ac.id.
}

\begin{abstract}
A research of dissolution testing of patent and generic glibenclamide tablet have been done. The purpose of this research is to determine quality of patent and generic glibenclamide tablet that circulated in Makassar. Glibenclamide tablets patent and generic dissolution have been tested with paddle methode in $500 \mathrm{ml}$ posfat buffer $\mathrm{pH} 7,4$, medium was accomplished at $37^{\circ} \mathrm{C} \pm 0,5$ the speed of $75 \mathrm{rpm}$. Aliquot retaken as much $5 \mathrm{ml}$ is done at time intervas of $10,20,30,45$, and 60 mnutes and then, the concentrations is confiruxed by spektrofotometer UV-VIS at the $299 \mathrm{~nm}$ wavelength. Based on the dissolution experiment result, the acquired glibenclamide percentage that was dissolute from glibenclamide tablets generic $A=$ $85,686 \%$, generic $B=81,336 \%$ and paten $=126,665 \%$ have fulfill the dissolution the condition according to British Pharmacphea 2008. That is the dissolute is not less than $75 \%$ within 45 minutes. And the average of Dissolution value efficiency (ED) rate each glibenclamide tablet paten $=115,29 \%$, generic $B=72,409 \%$ and generic $A=77,352 \%$.
\end{abstract}

Keywords : Glibenclamide patent and generic, dissolution, spektrofotometri UVVis.

\section{PENDAHULUAN}

Obat merupakan suatu faktor atau unsur yang memiliki peranan penting dalam lingkup kesehatan. Sebagian besar lingkup medis menggunakan obat sebagai standar dalam pengobatan atau penyembuhan penyakit. Oleh karena itu obat harus memiliki khasiat yang nyata dan berkualitas baik.

Obat yang beredar di masyarakat terdiri dari obat paten dan obat generik. Obat generik adalah obat yang beredar dengan nama resmi sesuai zat aktif yang dikandungnya dan dikemas secara sederhana. Sebaliknya obat paten memakai nama dagang dari pabrik yang memproduksi walaupun zat aktif yang dikandungnya sama ${ }^{8}$.

Dalam masa krisis ekonomi sekarang ini, harga obat semakin meningkat sehingga menurunkan keterjangkauan obat terutama untuk 
Perbandingan Mutu Berdasarkan Profil Disolusi Tablet Glibenklamid Paten Dan Generik Yang Beredar Di Makassar

masyarakat menengah ke bawah. Di Amerika Serikat penggunaan obat generik meningkat $63 \%$ pada tahun 1993 setelah FDA menetapkan uji bioekivalensi terhadap zat aktif yang terkandung dalam beberapa obat generik dengan obat pembandingnya ${ }^{5}$, sedangkan di Indonesia pada tahun 2001 penggunaanya mencapai $12 \%$ dan di tahun 2007 tinggal 7,23 $\%{ }^{10}$.

Faktanya, penerimaan obat generik oleh dokter maupun masyarakat sampai saat ini masih rendah karena dianggap kurang bermutu. Dokter juga seringkali memberikan resep non generik kepada pasien sebagai pilihan utama pengobatan, padahal harga obat paten biasanya lebih mahal dari obat generik, sehingga bagi pasien yang tidak mampu sering membeli setengah obat resep dokter. Hal ini sangat berbahaya, terutama bila obat tersebut adalah antibiotik ${ }^{10}$. Mutu dijadikan dasar acuan untuk menetapkan kebenaran khasiat (efikasi) dan keamanan (safety). Selain itu, mutu obat juga ditinjau dari bioavailabilitas (ketersediaan hayati) obat. Obat yang memiliki mutu fisik dan profil disolusi yang baik akan memberikan bioavailabilitas yang baik karena ketersediaan farmasetik dari obat tersebut tinggi ${ }^{10}$.
Untuk mengetahui perbandingan kualitas obat sediaan generik dengan sediaan paten perlu diketahui bioekuivalensi antara dua sediaan tersebut. Masing-masing sediaan diukur bioavailabilitasnya. Perbandingan bioavailabilitas ini disebut bioekivalansi obat. Dasar untuk menentukan bioavailabilitas suatu obat terlebih dahulu harus diketahui profil disolusinya ${ }^{10}$.

Salah satu obat yang terdapat dalam sediaan generik maupun sediaan paten, yaitu glibenklamid. Glibenklamid memiliki beberapa merk dagang dan generik yang beredar di pasaran dalam bentuk sediaan tablet.Glibenklamid adalah antidiabetik oral golongan sulfonilurea generasi kedua yang daya kerjanya lebih kuat daripada generasi pertama (tolbutamid, klorpropamid). Glibenklamid dapat menurunkan kadar glukosa darah pada penderita diabetes dan non-diabetes ${ }^{9}$.

Dalam

Biopharmaceutics Classification System (BCS), Glibenklamid termasuk kelas II atau obat yang kelarutannya rendah, tetapi memiliki permeabilitas yang tinggi, maka laju pelepasannya merupakan tahap yang paling menentukan absorbsinya ${ }^{3}$. 
Perbandingan Mutu Berdasarkan Profil Disolusi Tablet Glibenklamid Paten Dan Generik Yang Beredar Di Makassar

Sediaan tablet merupakan sediaan padat yang pelepasannya harus diperhatikan agar aktivitas farmakologinya dapat tercapai. Karena absorbsi dan kemampuan obat dalam sediaan tablet berada dalam tubuh sangat besar bergantung pada adanya zat aktif obat dalam keadaan melarut. Cepatnya obat dan tablet melarut biasanya menjadi sangat menentukan karena itu laju larut dapat berhubungan langsung dengan efikasi (kemanjuran) dari tablet dan perbedaan bioavailabilitas dari berbagai formula ${ }^{1}$.

Oleh karena itu, pengujian disolusi terhadap obat generik glibenklamid sangat penting untuk mengetahui perbandingan kualitas tablet glibenklamid generik dengan obat patennya sehingga mendorong penggunaan obat generik dalam pelayanan kesehatan dan membantu kesejahteraan masyarakat khususnya dalam bidang kesehatan.

Penelitian ini bertujuan untuk memperoleh data profil disolusi dari beberapa tablet glibenklamid generik dan paten yang beredar di Makassar sehingga dapat dibandingkan mutu dan kualitasnya. Penelitian ini diharapkan dapat menambah data ilmiah mengenai mutu (kualitas) dan bioekivalensi obat generik terhadap obat paten serta dapat dijadikan referensi untuk penelitian-penelitian selanjutnya.

\section{METODE PENELITIAN \\ Metode Kerja}

Penelitian ini dilakukan secara eksperimental, yang merupakan penelitian laboratorium dengan menggunakan rancangan eksperimental dengan melakukan pengujian mutu berdasarkan profil disolusi tablet sesuai dengan prosedur yang ditetapkan.

\section{Tempat/ Lokasi Dan Waktu Penelitian}

Penelitian dilaksanakan di laboratorium Farmaseutik Fakultas Farmasi Universitas Muslim Indonesia pada bulan Februari 2013 sampai selesai.

\section{Alat dan Bahan}

Adapun bahan-bahan yang digunakan adalah air suling, aluminium foil, dapar posfat $\mathrm{pH} 7,4$; glibenklamid baku (BPFI), tablet glibenklamid $5 \mathrm{mg}$ paten dan generik, kertas saring.

Adapun alat-alat yang digunakan adalah alat uji disolusi tipe keranjang (Veego), beker gelas 100 $\mathrm{ml}$, dan $250 \mathrm{ml}$ (pyrex), gelas ukur 50 dan $100 \mathrm{~mL}$ (pyrex), karet penghisap, labu tentukur $20 \mathrm{ml}, 50 \mathrm{ml}$, dan $100 \mathrm{ml}$ (pyrex),pH meter, pipet tetes, pipet volume $5 \mathrm{ml}$, spektrofotometer UV-VIS 
Perbandingan Mutu Berdasarkan Profil Disolusi Tablet Glibenklamid Paten Dan Generik Yang Beredar Di Makassar

(Thermo), timbangan analitik (o'haous), vial.

\section{Populasi dan Sampel}

Penelitian ini menggunakan populasi random acak dengan mengambil sampel obat di beberapa apotek berbeda yang ada di Makassar. Tablet glibenklamid diambil dari 3 produk (masing-masing 1 obat paten dengan inisial PA dan 2 obat generik dengan inisial GA dan GB dari pabrik yang berbeda) dari apotek yang beredar di Makassar.

\section{Prosedur kerja}

\section{Pembuatan Larutan Uji}

\section{Pembuatan larutan baku ${ }^{4}$}

Ditimbang secara seksama sejumlah lebih kurang 20 mg baku pembanding, dimasukkan kedalam labu tentukur $100 \mathrm{ml}$, dilarutkan dengan methanol sebanyak $5 \mathrm{ml}$, kemudian diencerkan dengan dapar posfat $\mathrm{pH} 7,4$ sampai tanda. Ukur absorban maksimum spektrofotometer UV-VIS.

\section{Perlakuan}

Jumlah produk tablet glibenklamid yang diuji disolusi adalah 2 produk untuk generik dan 1 produk untuk paten. Uji disolusi dilakukan terhadap masing-masing tablet.

Pengujian Disolusi ${ }^{5}$

Wadah disolusi diisi dengan medium disolusi sebanyak $500 \mathrm{ml}$

dapar posfat $0.05 \mathrm{M} \mathrm{pH} \mathrm{7,4,} \mathrm{kemudian}$ dibiarkan sampai suhu media mencapai $37 \pm 0,5^{\circ}$ C. Setelah suhu dicapai, masing-masing tablet dimasukkan ke dalam media sampai ujung bawah pengaduk berjarak $25 \pm 2$ $\mathrm{mm}$ dari bagian dalam labu, motor dijalankan dengan kecepatan 75 rpm. Pengambilan aliquot dilakukan pada menit ke- 10, 20, 30, 45, dan 60 sebanyak $5 \mathrm{ml}$. Pada setiap pengambilan aliquot, segera ditambahkan kembali dapar posfat $\mathrm{pH}$ 7,4 dengan volume dan suhu yang sama kedalam labu disolusi untuk mengganti larutan yang diambil. Menurut British Pharmacophea 2008 toleransi untuk disolusi glibenklamid/glyburid yaitu tidak kurang dari $75 \%$ zat aktif larut dalam 45 menit.

Penetapan kadar secara spektrofotometer UV ${ }^{4}$

Penentuan Panjang gelombang maksimum

Dibuat larutan glibenklamid dengan konsentrasi 100 ppm dalam dapar posfat $\mathrm{pH} 7,4$. Kemudian diukur serapannya pada panjang gelombang 200 - 360 nm. Rekam data, dapatkan absorbsi maksimum.

\section{Pembuatan kurva baku}

Dibuat satu seri larutan glibenklamid dalam dapar posfat $\mathrm{pH}$ 
Perbandingan Mutu Berdasarkan Profil Disolusi Tablet Glibenklamid Paten Dan Generik Yang Beredar Di Makassar

7,4 dengan konsentrasi waktu. Selanjutnya, dihitung nilai \% 4,6,8,10,12,14,16,18,20 ppm. ED (Efisiensi Disolusi).

Kemudian masing-masing konsentrasi diukur serapannya pada panjang gelombang maksimum. Dapatkan persamaan garisnya.

\section{Penetapan kadar glibenklamid hasil disolusi}

Jumlah glibenklamid yang terdisolusi pada tiap satuan waktu tertentu ditetapkan secara spektrofotometer dengan mengukur serapannya pada panjang gelombang maksimum dan dihitung kadarnya dengan menggunakan persamaan penyerapannya.

\section{Pengumpulan dan Pengolahan Data}

Data dan hasil pengukuran dan perhitungan kemudian dibuat tabel dan kurva antara jumlah glibenklamid yang terdisolusi tiap satuan waktu terhadap

\section{Analisis data}

Data yang diperoleh dari uji disolusi berupa kadar zat terlarut (Q) pada menit ke- 45 dibandingkan dengan persyaratan. Selain itu juga dihitung sebagai Dissolution Effisiency (ED) selama 60 menit dan selanjutnya dianalisis secara statistik.

\section{HASIL PENELITIAN}

\section{Penentuan Panjang Gelombang Maksimum}

Panjang gelombang maksimum glibenklamid dalam larutan dapar posfat pH 7,4 diperoleh $229 \mathrm{~nm}$.

\section{Pembuatan Kurva Baku}

Kurva baku larutan glibenklamid dalam dapar posfat $\mathrm{pH}$ 7,4 pada panjang gelombang maksimum 229 $\mathrm{nm}$ memenuhi persamaan garis lurusnya $Y=-0,005+0,038 x$.

Tabel 1. Hasil pengukuran serapan tablet glibenklamid dalam buffer posfat $\mathrm{pH} 7,4$ pada panjang gelombang maksimum (229 nm) untuk pembuatan kurva baku.

\begin{tabular}{cc}
\hline Konsentrasi (ppm) & Absorban \\
\hline 4 & 0,158 \\
6 & 0,220 \\
8 & 0,304 \\
10 & 0,375 \\
12 & 0,458 \\
14 & 0,515 \\
16 & 0,626 \\
18 & 0,683 \\
20 & 0,770 \\
\hline
\end{tabular}

Keterangan : Persamaan garis regresi untuk kurva baku (Gambar 1) adalah y $=-0,005+$ $0,038 x$ dengan koefisien korelasi $(r)=0,99891$. 
Perbandingan Mutu Berdasarkan Profil Disolusi Tablet Glibenklamid Paten Dan Generik Yang Beredar Di Makassar

\section{Uji Disolusi}

Setelah dilakukan uji disolusi, diperoleh persen rata-rata glibenklamid yang terdisolusi pada menit ke 45 untuk masing-masing tablet glibenklamid yaitu $\mathrm{GA}=$ $85,686 \% \mathrm{~GB}=81,336 \%$, dan $\mathrm{PA}=$ $126,665 \%$.

Tabel 2. Hasil perhitungan rata-rata persen kadar tablet glibenklamid yang terdisolusi.

\begin{tabular}{cccc}
\hline $\mathbf{T}$ & GA & GB & PA \\
\hline 0 & 0 & 0 & 0 \\
10 & 83,694 & 78,032 & 121,5581 \\
20 & 83,202 & 73,848 & 129,9978 \\
30 & 84,194 & 80,384 & 124,2271 \\
45 & 85,686 & 81,336 & 126,6652 \\
60 & 84,592 & 80,124 & 126,5498 \\
\hline
\end{tabular}

Keterangan :

$\mathrm{GA}=$ Generik $\mathrm{A} \quad \mathrm{GB}=$ Generik $\mathrm{B} \quad \mathrm{PA}=$ Paten $\mathrm{A}$

Penentuan Nilai Efisiensi Disolusi

Efisiensi Disolusi (\%ED) ratarata masing-masing tablet
72,409\%, dan $P A=115.291 \%$. Contoh perhitungan ED selengkapnya dapat dilihat pada lampiran

glibenklamid $\mathrm{GA}=77,352 \%, \mathrm{~GB}=$

Tabel 3. Hasil perhitungan Efisiensi Disolusi (ED) tablet glibenklamid

\begin{tabular}{|c|c|c|c|c|c|c|c|}
\hline \multirow{2}{*}{ Tablet } & \multicolumn{6}{|c|}{ Efisiensi Disolusi } & \multirow{2}{*}{$\begin{array}{l}\text { Rata- } \\
\text { Rata }\end{array}$} \\
\hline & 1 & 2 & 3 & 4 & 5 & 6 & \\
\hline GA & 82,299 & 55,500 & 78,002 & 81,165 & 83,762 & 83,384 & 77,352 \\
\hline GB & 75,528 & 46,292 & 60,210 & 86,330 & 84,942 & 81,155 & 72,4095 \\
\hline PA & 95,491 & 109,211 & 125,582 & 122,123 & 114,084 & 125,258 & 115,2915 \\
\hline $\begin{array}{l}\mathrm{GA} \\
\mathrm{GB} \\
\mathrm{PA}\end{array}$ & $\begin{array}{l}=\text { Gene } \\
=\text { Gene } \\
=\text { Pater }\end{array}$ & $\begin{array}{l}\text { rik A } \\
\text { rik B } \\
\text { A }\end{array}$ & & & & & \\
\hline
\end{tabular}

PEMBAHASAN

Uji disolusi digunakan untuk berbagai alasan dalam industri farmasi, yakni dalam pengembangan produk baru, untuk pengawasan mutu, dan untuk membantu menentukan kesetaraan hayati ${ }^{7}$.
Disolusi sering disebut pelepasan obat, merupakan proses yang terjadi ketika obat meninggalkan produk obat dan tersedia untuk mengalami absorbsi, distribusi, metabolisme, dan ekskresi (ADME) dan akhirnya tersedia untuk kerja 
Perbandingan Mutu Berdasarkan Profil Disolusi Tablet Glibenklamid Paten Dan Generik Yang Beredar Di Makassar

farmakologis. Saat ini, pengawasan mutu terhadap banyak produk obat didasarkan pada kinetika pelepasan obat secara in vitro ${ }^{7}$.

Penelitian ini dilakukan untuk mengetahui disolusi obat dari sediaan tablet glibenklamid paten dan generik dengan tujuan untuk membandingkan mutu obat generik terhadap obat patennya ditinjau dari profil disolusinya.

Penentuan panjang gelombang maksimum glibenklamid menggunakan kurva diperoleh nilai serapan maksimum 0,324 pada panjang gelombang maksimum ( $\left.\lambda_{\text {maks }}\right) 229 \mathrm{~nm}$. Penentuan panjang gelombang maksimum bertujuan untuk memperoleh kepekaan analisis yang optimal karena perubahan absorbsi untuk setiap satuan konsentrasi paling besar terletak pada panjang gelombang maksimum.

Uji disolusi dalam penelitian ini menggunakan alat tipe 2 atau metode dayung (paddle), medium yang digunakan untuk tablet glibenklamid 5 mg adalah dapar posfat pH 7,4. Uji disolusi dilakukan dengan pengaturan temperature dan kecepatan putar pengaduk yang dipertahankan selalu pada kondisi konstan, yaitu temperature dikendalikan pada suhu $37^{\circ} \pm 0,5^{\circ} \mathrm{C}$ dan kecepatan putar pada 75 rotasi per menit (rpm). Hal ini dimaksudkan bila terjadi kenaikan suhu selain dapat meningkatkan gradient konsentrasi (Cs) juga meningkatkan energy kinetika molekul obat yang besar kaitannya dengan tetapan difusi (D), sehingga berpengaruh pada peningkatan kecepatan pelarutan obat ${ }^{6}$.

Selain itu juga intensitas pengadukan harus dijaga supaya tetap, karena perubahan kecepatan pengadukan akan berpengaruh pada nilai $h$, yaitu tebalnya lapisan difusi atau stagnant layers yang terbentuk serta akan memperluas permukaan partikel yang kontak dengan pelarut sehingga berdampak pada peningkatan kecepatan pelarutan obat 6

Hasil yang diperlukan untuk menyatakan hasil uji kecepatan pelarutan menurut British Pharmacophea adalah 45 menit, karena diperkirakan zat aktif dalam tablet sudah larut tidak kurang dari $75 \%$. Adapun hasil perhitungan persen kadar zat terdisolusi dari ketiga produk pada menit ke- 45 yaitu untuk produk generik A (GA) yaitu $85,686 \%$, generik B (GB) yaitu $81,336 \%$, dan produk paten A (PA) yaitu $126,665 \%$. 
Perbandingan Mutu Berdasarkan Profil Disolusi Tablet Glibenklamid Paten Dan Generik Yang Beredar Di Makassar

Berdasarkan hasil tersebut, diketahui bahwa ketiga produk memenuhi persyaratan disolusi sesuai yang telah ditetapkan pada British Pharmacophea. Namun dari ketiga produk tersebut, produk paten A (PA) memiliki kadar pelepasan rata-rata lebih dari $5 \mathrm{mg}$, yang melebihi kadar yang diklaim pada produk yakni $5 \mathrm{mg}$. Hal ini kemungkinan disebakan oleh adanya perubahan kadar yang terjadi selama distribusi obat seperti kondisi penyimpanan yang tidak sesuai, atau kemungkinan adanya kesalahan pada saat pengukuran yakni sensitivitas dari kuvet yang digunakan. Hal ini tidak dapat dijelaskan secara terperinci karena tidak dilakukannya pengujian keseragaman kandungan untuk mengetahui kandungan zat aktif pada produk, dimana pada persyaratkan bahwa keseragaman kandungan zat aktif suatu sediaan tablet yaitu 85$115 \%$.

Parameter lain yang digunakan untuk menyatakan uji disolusi adalah DE (Dissolution Effisiency) yang menyatakan perbandingan antara luas daerah dibawah kurva kecepatan pelarutan dan daerah pada waktu yang sama menggambarkan $100 \%$ obat terlarut dalam medium. Pengukuran hasil proses disolusi dalam Dissolution Effisiency (DE) lebih sering digunakan karena mampu menggambarkan seluruh proses yang terjadi.

Untuk mengetahui Dissolution Effisiency pada waktu 60 menit $\left(\mathrm{DE}_{60}\right)$, maka pengamatan uji disolusi dilakukan selama 60 menit, karena dalam waktu tersebut diperkirakan zat aktif dalam tablet sudah terlarut lebih dari $75 \%$.

Dari hasil penelitian, diperoleh hasil uji disolusi dari tablet glibenklamid yang menunjukkan bahwa hasil disolusi tablet GA, GB dan PA berbeda-beda. Hasil disolusi produk GA dan GB hampir sama sedangkan untuk produk PA berbeda dari kedua produk generik tersebut. Hal ini terlihat pada nilai Efisiensi disolusi dari ketiga produk, dimana nilai ED terbesar pada produk PA sebesar 115,291\%, dan ED terkecil pada produk GA sebesar $77,352 \%$ sedangkan produk GB sebesar $72,409 \%$.

Setelah dianalisis secara statistik menggunakan rancangan acak lengkap menunjukkan bahwa nilai efisiensi disolusi dari tablet glibenklamid generic $A$, generic $B$, dan paten $\mathrm{A}$ berbeda nyata pada taraf $5 \%$ dan $1 \%$ dengan nilai $\mathrm{FH}$ lebih besar dari FT. Hasil analisis JNTD (Jarak Nyata Terdekat Duncan) untuk 
Perbandingan Mutu Berdasarkan Profil Disolusi Tablet Glibenklamid Paten Dan Generik Yang Beredar Di Makassar

efisiensi disolusi (\%ED), menunjukkan ada beda nyata antara tablet glibenklamid GA dengan $P A$, dan tablet glibenklamid GB dengan PA sedangkan untuk tablet glibenklamid GA dan GB tidak berbeda nyata pada taraf signifikan $5 \%$ dan $1 \%$.

Hal ini mengindikasikan bahwa tablet glibenklamid $5 \mathrm{mg}$ sediaan generik tidak menunjukkan kesetaraan mutu terhadap obat patennya jika ditinjau dari profil disolusi dari masingmasing produk. Namun, meskipun demikian ketiga produk tersebut telah memenuhi syarat uji yang ditetapkan oleh British Pharmacophea 2008.

Adapun perbedaan kualitas atau hasil disolusi tablet glibenklamid produk GA, GB, dan PA kemungkinan disebabkan oleh faktor formulasi obat yang berbeda dari masing-masing pabrik seperti ukuran partikel, jumlah dan tipe bahan pengisi, atau disebabkan karena faktor distribusi dan kondisi pentimpanan sampel dari masing-masing pabrik.

\section{KESIMPULAN}

1. Tablet glibenklamid generik $A(G A)$, generik $B(G B)$, dan paten $A(P A)$ memenuhi syarat uji disolusi menurut British Pharmacophea 2008 berdasarkan nilai Q (persen obat yang terlepas) pada waktu 45 menit.
2. Dari hasil perhitungan kadar disolusi yang dihitung dan berdasarkan efisiensi disolusi $\left(\% \mathrm{ED}_{60}\right)$ untuk masing-masing sediaan Paten A (PA), Generik A (GA), dan Generik B (GB) menunjukkan bahwa sediaan glibenklamid generik tidak memiliki kesetaraan mutu terhadap sediaan patennya jika ditinjau dari profil disolusinya.

\section{DAFTAR PUSTAKA}

1. Ansel. Pengantar Bentuk Sediaan Farmasi Edisi 4. UI.Press : Jakarta, 1989.

2. British Pharmacopoeia. Medicines and Healthcare Products regulatory Agency (MHRA) : London, 2008.

3. Department of Health. Medicine Countrol Council Disolution. Repoublic of South Africa, p2011.

4. Departement Of Pharmaceutics. The International Pharmacopoeia Fourth Edition Volume 2, Bangalore : India, 2006.

5. FDA. Recommended Dissolutin Methods, Silver Spring : USA, 2004.

6. Hadi, Indriyati S et al. Uji Sifat Fisik dan Disolusi Tablet Isosorbit Dinitrat $5 \mathrm{mg}$ Sediaan Generik dan Sediaan Dengan Nama Dagang yang Beredar Di Pasaran (skripsi). Universitas Wahid Hasyim : Semarang, 2012.

7. Sinko, Patrick J. Farmasi Fisika dan IImu Farmaseutika Edisi V. 
Perbandingan Mutu Berdasarkan Profil Disolusi Tablet Glibenklamid Paten Dan Generik Yang Beredar Di Makassar

Penerbit Bku Kedokteran. EGC, 2006.

8. Siregar CJP. Pengawasan Mutu Obat Generik Berlogo. Phyto Medica 1 : Jakarta, 1989.

9. Tjay HT, Rahardja K. Obat-obat penting: khasiat, penggunaan, dan efek-efek sampingnya $5^{\text {th }}$ ed. PT Elex Media Komputindo : Jakarta, 2002.

10.Zubaedah I. Perbandingan Mutu Fisik dan Profil Disolusi Tablet IbuprofenMerk Dagang dan Generik (skripsi). Universitas Muhammadiyah Surakarta Surakarta, 2009. 